\title{
SISTEM SKORING UNTUK MEMPREDIKSI KEJADIAN HIPERTENSI PADA USIA PRODUKTIF DI KOTA MEDAN (PRELIMINARY STUDY)
}

\author{
Yohanes Firmansyah ${ }^{1}$, Ernawati $^{2}$, Evy Luciana Prawiro ${ }^{3}$ \\ ${ }^{1}$ Departemen Ilmu Kesehatan Masyarakat, Fakultas Kedokteran Universitas Tarumanagara, Jakarta \\ Email: yohanesfirmansyah28@gmail.com \\ ${ }^{2}$ Departemen Ilmu Kesehatan Masyarakat, Fakultas Kedokteran Universitas Tarumanagara, Jakarta \\ Email:dr.ernawati@gmail.com \\ ${ }^{3}$ Departemen Ilmu Kesehatan Masyarakat, Fakultas Kedokteran Universitas Tarumanagara, Jakarta \\ Email: panpantitot@yahoo.com
}

Masuk: 24-11-2019, revisi: 02-03-2020, diterima untuk diterbitkan: 07-05-2020

\begin{abstract}
ABSTRAK
Hipertensi merupakan penyakit kronis yang menyerang semua usia dengan penyebab multifaktor, terutama gaya hidup. Tujuan penelitian untuk mengetahui faktor risiko pada usia produktif untuk memprediksi kemungkinan terkena hipertensi dikemudian hari. Metode yang digunakan adalah Potong lintang pada responden di beberapa pabrik dan kantor di Kota Medan periode Agustus 2014, serta variabel bebas diuji dengan uji chi-square lalu dilakukan uji lanjutan multivariat. Hasil Penelitian yaitu 352 responden yang memenuhi kriteria inklusi. terdapat 118 menderita hipertensi. Analisa multivariat dilakukan pada variabel jenis kelamin, status gizi, konsumsi garam, konsumsi makanan cepat saji, olahraga, merokok, alkohol, penghasilan, banyak anak, kurang tidur, kondisi psikologi, konsumsi makanan berlemak, konsumsi makanan tinggi sayur dan buah, konsumsi kopi-teh-soda, penyakit kronis, konsumsi obat rutin, dan pil KB. Faktor risiko yang dapat diperkirakan sebagai alat prediksi kejadian hipertensi pada kelompok usia produktif (analisis secara "Backward LR, p-value $<0.001$ ), yaitu konsumsi garam (p-value <0,001), konsumsi junkfood (p-value 0,001), lama tidur kurang dari 6 jam (p-value 0,008), konsumsi sayur (p-value 0,039), dan penyakit kronis (p-value 0,006). Kesimpulan yang didapatkan yaitu bahwa Lima variabel bebas yaitu konsumsi garam, makanan cepat saji, sayuran, lama tidur kurang dan penyakit kronis berperan secara mandiri terhadap hipertensi. Kami merekomendasikan skoring prognostik untuk hipertensi pada usia produktif ini digunakan setelah dilakukan uji lanjutan berupa uji kesahihan dan kehandalan.
\end{abstract}

Kata Kunci: hipertensi; skoring prognostik; usia produktif

\begin{abstract}
Hypertension is a chronic disease that attacks all ages, with multifactorial cause especially lifestyle. The purpose of this study was to determine risk factors for productive age to predict the likelihood of developing hypertension in the future. Methods used Cross-sectional method was applied to the respondents in several factories and offices in Medan in August 2014, and the independent variables were tested using the chi-square test and then conducted a multivariate follow-up test. As Results, 352 respondents who met the inclusion criteria. there are 118 suffering from hypertension. Multivariate analysis was carried out on gender, nutritional status, salt consumption, fast food consumption, exercise, smoking, alcohol, income, amount of children, lack of sleep, psychological conditions, consumption of fatty foods, consumption of foods high in vegetables and fruits, consumption of coffee-soda-tea, chronic disease, routine drug consumption, and contraception pills. The risk factors that can be estimated as predictors of hypertension in the productive age group (backward LR analysis, p-value <0.001, i.e. salt consumption (p-value <0.001), junk food consumption (p-value 0.001), sleep less than 6 hours ( $p$-value 0.008), vegetable consumption (p-value 0.039), and chronic diseases (p-value 0.006). Conclusion of the study are Five independent variables, salt consumption, fast food, vegetables, lack of sleep and chronic diseases that play role independently of hypertension. We recommend that prognostic scoring for hypertension at productive age be used after further testing in the form of validity and reliability.
\end{abstract}

Keywords: hypertension; Prognostic scoring; productive age 


\section{PENDAHULUAN}

\section{Latar Belakang}

Definisi Hipertensi atau tekanan darah tinggi adalah peningkatan tekanan darah sistolik lebih dari $140 \mathrm{mmHg}$ dan tekanan darah diastolik lebih dari $90 \mathrm{mmHg}$ pada dua kali pengukuran dengan selang waktu lima menit dalam keadaan cukup istirahat/tenang. Peningkatan tekanan darah yang berlangsung dalam jangka waktu lama (persisten) dapat menimbulkan kerusakan pada ginjal (gagal ginjal), jantung (penyakit jantung koroner) dan otak (menyebabkan stroke) bila tidak dideteksi secara dini dan mendapat pengobatan yang memadai. Banyak pasien hipertensi dengan tekanan darah tidak terkontrol dan jumlahnya terus meningkat. Oleh karena itu, partisipasi semua pihak, baik dokter dari berbagai bidang peminatan hipertensi, pemerintah, swasta maupun masyarakat diperlukan agar hipertensi dapat dikendalikan. (Kemenkes.RI, 2014)

Hipertensi sendiri masuk kedalam anggota penyakit tidak menular. Secara global, pada tahun 2016, penyakit tidak menular menyumbang 41 juta $(71 \%)$ kematian dari 57 juta kematian. Penyebab kematian terbesar adalah penyakit kardiovaskular dan hipertensi sebesar 17,9 juta kematian (44\% dari semua kematian penyakit tidak menular dan $31 \%$ dari semua penyebab kematian global), kanker sebesar 9 juta kematian (22\% dari semua kematian penyakit tidak menular dan $16 \%$ dari semua penyebab kematian global), penyakit pernafasan kronis sebesar 3,8 juta kematian $(9 \%$ dari semua kematian penyakit tidak menular dan 7 dari semua penyebab kematian global), serta diabetes mellitus tipe 2 sebesar 1,6 juta kematian (4\% dari semua kematian penyakit tidak menular dan 3\% dari semua penyebab kematian global). Hal yang lebih mengkhawatirkan adalah $75 \%$ kasus kematian akibat penyakit tidak menular terjadi pada populasi usia dewasa muda. (Amruth, Mullick, Balakrishna, \& Prabhudeva, 2015; World Health Organization, 2014, 2016, 2018)

Hasil Riset Kesehatan Dasar (Riskesda) Badan Penelitian dan Pengembangan Kesehatan tahun 2013 menunjukkan prevalensi penderita hipertensi di Indonesia secara nasional mencapai 25,8\%. Berdasarkan data dari profil masing-masing provinsi didapatkan bahwa prevalensi di pulau Sumatera lebih dari 21\%, dalam rentang masing-masing provinsi adalah 20,9\% hingga 30,9\%. Prevalensi penderita hipertensi di Sumatera Utara sendiri mencapai 24,7\%. (Badan Penelitian dan Pengembangan Kesehatan, 2013)

Seseorang dikatakan mengkonsumsi garam berlebih apabila asupan garamnya diatas 6 gram per hari (WHO) atau memiliki kadar natrium lebih dari $200 \mathrm{mg}$ di dalam plasma darah. Garam yang dikonsumsi sehari-hari terdiri dari ion natrium dan klorida. Natrium sendiri merupakan kation yang terdapat banyak di cairan ekstraseluler, air, dan substansi rongga luar sel. Konsentrasi normal dalam serum adalah 136-145 mEq/L. Fungsi dari natrium ini adalah sebagai ion utama di cairan ekstraseluler dan volume plasma tubuh. Natrium juga membantu dalam penghantaran rangsang saraf dan kontraksi otot. (Chobanian, 2017). Garam dalam kondisi yang berlebih mempunyai dampak dalam fisiologi tubuh. Garam-garam yang berlebihan ini akan meningkatkan volume plasma dalam tubuh. Peningkatan volume plasma dalam tubuh yang disebabkan oleh natrium yang berlebihan menyebabkan konsentrasi natrium di dalam cairan ekstraseluler meningkat. Untuk menormalkannya, maka fisiologi tubuh akan menarik cairan intraseluler yang pada proses selanjutnya akan menyebabkan meningkatnya volume cairan ekstraseluler. Dalam proses ekskresi pun, garam-garam natrium ini akan menyebabkan retensi cairan di dalam tubuh manusia sehingga terjadi penimbunan cairan di dalam tubuh. Mekanisme peningkatan volume darah yang menyebabkan terjadinya retensi air di dalam tubuh akan mengakibatkan volume plasma dalam tubuh pun meningkat. Kombinasi dari peningkatan volume dalam tubuh manusia dengan konstriksi dari pembuluh vena, maka akan berdampak pada peningkatan preload yang akhirnya 
jika berinteraksi dengan faktor lain akan menuntut jantung untuk meningkatkan pompa dan curah jantung. Hal ini akan tampak dampak klinisnya yaitu berupa peningkatan tekanan darah pada orang tersebut. (Ando \& Fujita, 2012; Chobanian, 2017)

Makanan junkfood adalah makanan yang memiliki nilai gizi yang rendah. Junkfood sendiri memiliki kandungan gula, lemak, garam, serta minyak yang sangat banyak. Di dalam darah, lemak akan berikatan dengan protein globulin disebut lipoprotein selama proses pengangkutannya. Dari hasil penelitian terbaru, pengikatan lemak dengan lipoprotein ternyata diperantarai oleh hormon aldosteron yang sangat berperan dalam keseimbangan sistem reninangiostensin. Pada prosesnya renin akan memicu peningkatan produksi aldosteron dan aldosteron sendiri akan memicu ketidakseimbangan sistem renin di ginjal yang memicu peningkatan natrium dan terjadinya retensi di dalam tubuh. Hal ini akan berdampak pada peningkatan tekanan darah yang memiliki mekanisme sama persis dengan pengaruh natrium terhadap tekanan darah. (J. E. Hall et al., 2012; Zhao et al., 2011) Hasil studi selanjutnya, ternyata lemak-lemak ini juga meningkatkan tekanan darah melalui penyumbatan pembuluh darah yang mengakibatkan gangguan pengangkutan oksigen dan zat-zat makanan ke organ-organ penting. Penyempitan ini akan memaksa jantung untuk meningkatkan kinerjanya dan memompa lebih kuat lagi agar dapat memenuhi kebutuhan dari sel-sel target akan pasokan makanan. Proses ini akan berdampak pula pada peningkatan tekanan darah. (J. E. Hall et al., 2015; Zhao et al., 2011).

Buah dan sayuran memiliki kandungan kalium yang cukup tinggi. Kalium dalam fisiologi dan kegunaannya dalam tubuh manusia berperan sebagai diuretik (merangsang pengeluaran urin pada manusia) sehingga akan meningkatkan pengeluaran natrium dan menghambat pengeluaran renin yang akan mengakibatkan berubahnya sistem renin angiostensin. Selain itu, kalium sendiri merupakan ion utama di dalam cairan intraseluler dimana asupan tinggi kalium akan meningkatkan konsentrasinya di dalam cairan intraseluler. Hal ini akan menarik cairan dari ekstraseluler yang berakibat pada menurunnya tekanan darah menjadi lebih stabil atau normal. Sayuran dan buah juga mengandung unsur lain seperti magnesium, pektin dan serat. Hal ini berkaitan dengan tekanan darah pada manusia, magnesium sendiri mempunyai fungsi sebagai vasodilator pada koroner dan arteri periferal. Pektin atau serat yang larut air memiliki kemampuan mengikat substansi yang membentuk kolesterol dan membuangnya dari tubuh sehingga dapat menghambat proses aterosklerosis, menurunkan viskositas melalui ikatannya dengan kolesterol, dan menurunkan tekanan darah. (Ando \& Fujita, 2012; Houston, 2011; Perez \& Chang, 2014; Stolarz-Skrzypek et al., 2013).

Tidur dalam prosesnya dibagi menjadi dua tahapan besar, yaitu tahapan mata cepat (tidur tidak nyenyak) atau Rapid Eye Movement (REM) dan pergerakan mata tidak cepat (tidur nyenyak) atau Non-Rapid Eye Movement (NREM). Durasi tidur yang pendek ini akan berdampak pada berbagai aspek kehidupan manusia. Salah satu aspek yang paling terpengaruh adalah aspek kesehatan dan tekanan darah. Dengan durasi tidur yang singkat dan kualitas tidur yang buruk pula, akan membuat fase tidur REM dan NREM menjadi berkurang. Penurunan fase NREM mengakibatkan peningkatan aktivitas dari neuron monoaminergik yang selanjutnya akan menstimulasi pengeluaran hormon noradrenergik dan serotonergik yang berfungsi meningkatkan denyut jantung dan menyebabkan kontriksi pembuluh darah. Penurunan fase REM sendiri berdampak pada penurunan aktivitas dari neuron kolinergik atau neuron retikuler pons yang berfungsi menenangkan dan membuat rileks individu. Perubahan di kedua fase REM dan NREM 
ini akan berdampak pada peningkatan tekanan darah. Selain mengurangi durasi fase REM dan NREM, singkatnya durasi tidur juga akan mempengaruhi sistem otonom manusia, berupa peningkatan kinerja sistem saraf simpatis dan penurunan kinerja sistem saraf parasimpatis yang memicu peningkatan tekanan darah. (Jike et al., 2018; Knutson, 2010; Pepin et al., 2014; Wang et al., 2012)

Kota Medan yang merupakan bagian dari kota di Sumatera menjadi subyek penelitian penulis untuk mengetahui prevalensi penderita hipertensi di kota tersebut dikarenakan sebelumnya belum adanya penelitian mengenai prevalensi hipertensi di kota Medan. Selain itu dari berbagai faktor risiko pencetus hipertensi, seperti asupan garam dan mineral, demografi, genetik dan riwayat keluarga, pola hidup, indeks massa tubuh, kontrasepsi hormonal, konsumsi obat lainnya, keadaan psikologi, lingkungan, status sosial dan ekonomi, dan penyakit, masih belum dapat ditentukan faktor apa yang dominan menjadi pencetus kejadian hipertensi.

\section{Rumusan Masalah}

Prevalensi hipertensi pada kelompok usia produktif sangatlah tinggi. Penelitian ini dilakukan untuk memprediksi faktor risiko hipertensi apa yang dominan mencetuskan kejadian hipertensi pada usia produktif, serta dibentuk skoring prognostik untuk memperkirakan kemungkinan kejadian hipertensi di kemudian hari pada usia produktif yang masih sehat

\section{METODE PENELITIAN}

Penelitian ini merupakan penelitian observasional dengan desain penelitian potong lintang yang dilaksanakan di beberapa pabrik dan kantor di Kota Medan pada periode 6 Agustus 2014 - 13 Agustus 2014. Sampel penelitian ini adalah semua pekerja yang datang ke tempat pemeriksaan di beberapa pabrik yang menjadi tempat pengambilan sampel pada Agustus 2014 dan memenuhi kriteria inklusi. Perkiraan besar sampel pada penelitian ini yaitu sebesar 776 responden dengan metode pengambilan sampel berupa non-random consecutive sampling.

Kriteria inklusi dalam penelitian ini adalah semua responden usia produktif atau 20-56 tahun, tanpa memandang jenis kelamin, pekerjaan, ras, indeks massa tubuh (IMT), konsumsi garam, konsumsi junkfood, olahraga, penghasilan, riwayat keluarga, rokok, alkohol, jumlah anak, lama tidur, stress/psikologi, konsumsi lemak, konsumsi sayuran, konsumsi buah-buahan, konsumsi kacang-kacangan, konsumsi kopi/teh/soda, menderita penyakit kronik, konsumsi obat-obatan (seperti: pil kontrasepsi, obat anti radang, obat penambah darah, obat pilek/flu, obat anti nyeri, dan suplemen), dan kondisi tekanan darahnya.

Kriteria eksklusi pada penelitian adalah hipertensi sekunder. Seluruh variabel baik variabel tergantung dan variabel bebas dinilai menggunakan kuesioner dan instrument terkait. Pengukuran konsumsi makanan atau zat gizi seperti konsumsi garam, buah-buahan, junkfood, sayuran, kacang-kacangan menggunakan kuesioner khusus berupa Food Frequency Quesionnaire (FFQ), dan pengukuran tekanan darah menggunakan tensi meter merek Riester dan stetoskop merek Litman. Analisis statistik menggunakan uji statistik Chi square with Yates Correction untuk menilai kemaknaan antar 2 variabel dan dilanjutkan dengan binary logistik "Backward $L R$ ” untuk melihat faktor risiko yang dominan mencetuskan hipertensi. Penelitian ini telah mendapatkan izin dari Fakultas Kedokteran Universitas Tarumanagara. Surat keterangan penelitian ini dilampirkan kepada redaksi yang terdiri dari 4 surat yaitu surat No.060/UU/VIII/14 ; surat No.015/VIII/2014 ; surat No.013/VIII/2014 ; surat No.027/SCA/VIII/14. 


\section{HASIL DAN PEMBAHASAN}

Penelitian berlangsung dengan mengikutsertakan 352 responden dan didapatkan prevalensi hipertensi sebesar 33,5\% atau 118 dari 352 responden mengidap hipertensi. Uji statistik Chi Square with Yates Correction didapatkan hasil terdapat hubungan bermakna antara jenis kelamin, IMT, konsumsi garam dan junkfood, olahraga, alkohol, penghasilan, jumlah anak, lama tidur, psikologi, konsumsi lemak, sayur, buah-buahan serta penyakit kronis lainnya terhadap kejadian hipertensi ( $p$-value: $<0,05)$.

Tabel 1. Hubungan antara Berbagai Faktor Resiko dengan Hipertensi di Beberapa Pabrik dan Kantor di Kota Medan

\begin{tabular}{|c|c|c|c|c|c|c|c|c|c|}
\hline \multicolumn{2}{|c|}{ Parameter } & \multicolumn{2}{|c|}{ Hipertensi } & \multicolumn{2}{|c|}{$\begin{array}{c}\text { Tidak } \\
\text { Hipertensi }\end{array}$} & \multirow[t]{2}{*}{ PR } & \multicolumn{2}{|c|}{ IK $95 \%$} & \multirow[t]{2}{*}{$p$} \\
\hline & & $\mathbf{N}$ & $\%$ & $\mathbf{N}$ & $\%$ & & Min & Maks & \\
\hline Jenis & Laki-laki & 48 & $42,5 \%$ & 65 & $57,5 \%$ & 1,450 & 1,084 & 1,941 & 0,014 \\
\hline Kelamin & Wanita & 70 & $29,3 \%$ & 169 & $70,7 \%$ & & & & \\
\hline \multirow[t]{2}{*}{ IMT } & Obesitas & 75 & $45,5 \%$ & 90 & $54,5 \%$ & 1,977 & 1,448 & 2,698 & $<0,001$ \\
\hline & Normal & 43 & $23,0 \%$ & 144 & $77,0 \%$ & & & & \\
\hline Konsumsi & Berlebih & 112 & $64,0 \%$ & 63 & $36,0 \%$ & 18,88 & 8,532 & 41,779 & $<0,001$ \\
\hline Garam & Cukup/rendah & 6 & $3,4 \%$ & 171 & $96,6 \%$ & & & & \\
\hline Konsumsi & Berlebih & 95 & $57,6 \%$ & 70 & $42,4 \%$ & 4,681 & 3,124 & 7,015 & $<0,001$ \\
\hline Junk Food & Cukup/rendah & 23 & $12,3 \%$ & 164 & $87,7 \%$ & & & & \\
\hline \multirow[t]{2}{*}{ Olahraga } & Tidak & 111 & $35,9 \%$ & 198 & $64,1 \%$ & 2,2 & 1,102 & 4,417 & 0,011 \\
\hline & $\mathrm{Ya}$ & 7 & $36,3 \%$ & 36 & $83,7 \%$ & & & & \\
\hline Riwayat & $\mathrm{Ya}$ & 66 & $36,3 \%$ & 116 & $63,7 \%$ & 1,186 & 0,881 & 1,596 & 0,260 \\
\hline keluarga & Tidak & 52 & $30,6 \%$ & 118 & $69,4 \%$ & & & & \\
\hline \multirow[t]{2}{*}{ Rokok } & $\mathrm{Ya}$ & 40 & $54,8 \%$ & 33 & $45,2 \%$ & 1,96 & 0,881 & 1,596 & $<0,001$ \\
\hline & Tidak & 78 & $28,0 \%$ & 201 & $72,0 \%$ & & & & \\
\hline \multirow[t]{2}{*}{ Alkohol } & $\mathrm{Ya}$ & 24 & $80,0 \%$ & 6 & $20,0 \%$ & 2,74 & 2,141 & 3,508 & $<0,001$ \\
\hline & Tidak & 94 & $29,2 \%$ & 228 & $70,8 \%$ & & & & \\
\hline \multirow[t]{2}{*}{ Penghasilan } & $<$ UMR & 12 & $20,7 \%$ & 46 & $79,3 \%$ & 0,574 & 0,339 & 0,971 & 0,023 \\
\hline & $\geq \mathrm{UMR}$ & 106 & $36,1 \%$ & 188 & $63,1 \%$ & & & & \\
\hline \multirow{2}{*}{ Jumlah Anak } & $>2$ anak & 35 & $25,4 \%$ & 103 & $74,6 \%$ & 0,654 & 0,469 & 0,911 & 0,009 \\
\hline & $\leq 2$ anak & 83 & $38,8 \%$ & 131 & $61,2 \%$ & & & & \\
\hline \multirow[t]{2}{*}{ Lama Tidur } & $<6$ jam & 49 & $56,3 \%$ & 38 & $43,7 \%$ & 2,163 & 1,644 & 2,847 & $<0,001$ \\
\hline & $\geq 6 \mathrm{jam}$ & 69 & $26,0 \%$ & 196 & $74,0 \%$ & & & & \\
\hline \multirow[t]{2}{*}{ Psikologi } & Stress & 35 & $26,3 \%$ & 98 & $73,7 \%$ & 0,694 & 0,499 & 0,967 & 0,026 \\
\hline & Baik & 83 & $37,9 \%$ & 136 & $62,1 \%$ & & & & \\
\hline Konsumsi & Berlebih & 82 & $38,0 \%$ & 134 & $62,0 \%$ & 1,434 & 1,033 & 1,991 & 0,026 \\
\hline Lemak & Rendah/cukup & 36 & $26,5 \%$ & 100 & $73,5 \%$ & & & & \\
\hline \multirow{2}{*}{ Sayur } & Rendah sayur & 31 & $66,0 \%$ & 16 & $34,0 \%$ & 2,312 & 1,762 & 3,034 & $<0,001$ \\
\hline & Cukup/baik & 87 & $28,5 \%$ & 218 & $71,5 \%$ & & & & \\
\hline \multirow[t]{2}{*}{ Buah-buahan } & Rendah buah & 43 & $49,4 \%$ & 44 & $50,6 \%$ & 1,746 & 1,312 & 2,325 & $<0,001$ \\
\hline & Cukup/baik & 75 & $28,3 \%$ & 190 & $71,7 \%$ & & & & \\
\hline \multirow[t]{2}{*}{ Kacang } & Rendah & 61 & $34,9 \%$ & 114 & $65,1 \%$ & 1,08 & 0,806 & 1,453 & 0,598 \\
\hline & Tinggi & 57 & $32,2 \%$ & 120 & $67,8 \%$ & & & & \\
\hline \multirow{4}{*}{$\begin{array}{l}\text { Kopi, T } \\
\text { Soda } \\
\text { Penyakit } \\
\text { kronik }\end{array}$} & Tinggi & 76 & $30,8 \%$ & 171 & $69,2 \%$ & 0,769 & 0,570 & 1,038 & 0,093 \\
\hline & Cukup/rendah & 42 & $40,0 \%$ & 63 & $60,0 \%$ & & & & \\
\hline & Ya & 25 & $62,5 \%$ & 15 & $37,5 \%$ & 2,097 & 1,562 & 2,814 & $<0,001$ \\
\hline & Tidak & 93 & $29,8 \%$ & 219 & $70,2 \%$ & & & & \\
\hline
\end{tabular}

Analisa multivariat dilakukan pada variabel jenis kelamin, status gizi, konsumsi garam, konsumsi makanan cepat saji, olahraga, merokok, alkohol, penghasilan, banyak anak, kurang tidur, kondisi psikologi, konsumsi makanan berlemak, konsumsi makanan tinggi sayur dan buah, 
konsumsi kopi-teh-soda, penyakit kronis, konsumsi obat rutin, dan pil KB dan menghasilkan data bahwa ada 5 variabell yang dominan sebagai faktor risiko yang dapat diperkirakan sebagai alat prediksi kejadian hipertensi pada kelompok usia produktif (analisis secara "Backward LR, pvalue $<0.001)$

Tabel 2. Binary Logistik "Backward LR" Berbagai Faktor Resiko dengan Hipertensi di Beberapa Pabrik dan Kantor di Kota Medan

\begin{tabular}{llcccccr}
\hline Step & \multicolumn{1}{c}{ Faktor Risiko } & $\boldsymbol{B}$ & S.E. & Wald & $\boldsymbol{d f}$ & \multicolumn{1}{c}{ Sig. } & $\boldsymbol{E x p ( \boldsymbol { B } )}$ \\
\hline Step & IMT(1) &, 587 &, 349 & 2,826 & 1 &, 093 & 1,799 \\
$9^{\text {a }}$ & Garam(1) & 3,570 &, 499 & 51,078 & 1 &, 000 & 35,503 \\
& Junkfood(1) & 1,276 &, 372 & 11,762 & 1 &, 001 & 3,584 \\
& Anak(1) &,- 648 &, 359 & 3,248 & 1 &, 072 &, 523 \\
& Tidur(1) & 1,218 &, 456 & 7,135 & 1 &, 008 & 3,381 \\
& Sayur(1) & 1,325 &, 642 & 4,260 & 1 &, 039 & 3,761 \\
& Buah(1) &,- 960 &, 546 & 3,091 & 1 &, 079 &, 383 \\
& Penyakit lain (1) & 1,632 &, 590 & 7,642 & 1 &, 006 & 5,112 \\
& Konsumsi Obat anti- & 1,713 &, 934 & 3,366 & 1 &, 067 & 5,548 \\
& nyeri responden(1) & & & & & & \\
& Konsumsi Obat & 1,069 &, 553 & 3,730 & 1 &, 053 &, 343 \\
& Kontrasepsi responden & & & & & & \\
& Constant & $-4,563$ &, 547 & 69,530 & 1 &, 000 &, 010 \\
\hline
\end{tabular}

a. Variable(s) entered on step 1: Jenis Kelamin Responden, IMT, Garam, Junk Food, Olah raga, Riwayat merokok (non-smoker vs current-smoker/ever-smoker), Riwayat minum alkohol dalam 1 bulan terakhir, penghasilan, Anak, Tidur, psikologi, Konsumsi makanan yang berlemak, Sayur, Buah, Konsumsi kopi dan teh responden, Penyakit lain yang diderita oleh responden, Konsumsi Obat anti-nyeri responden, Konsumsi Obat Kontrasepsi responden.

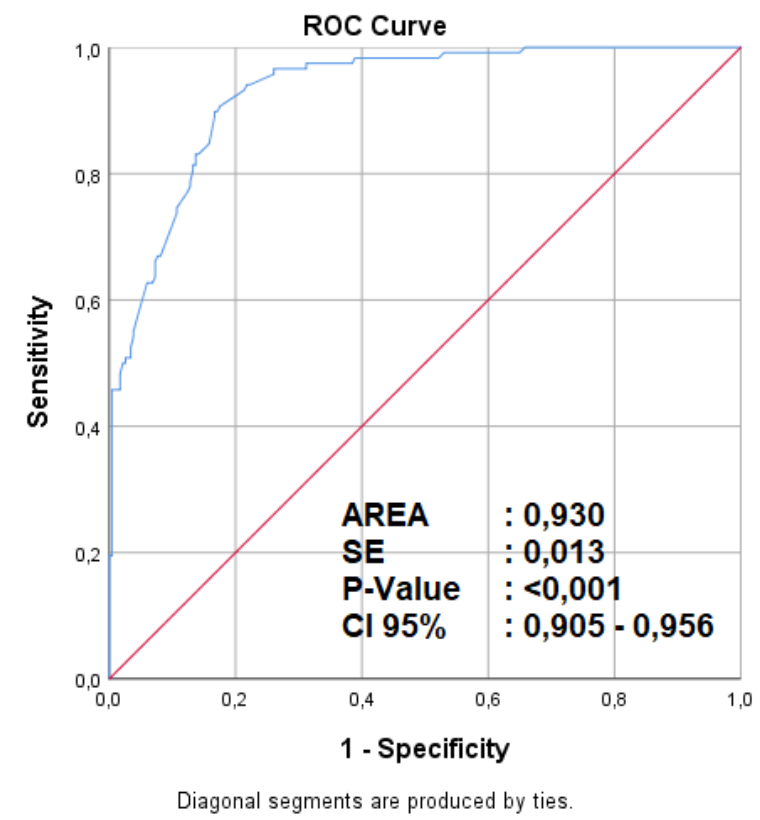

Gambar 1. Kurva ROC Binary Logistik “Backward LR” Berbagai Faktor Resiko dengan Hipertensi di Beberapa Pabrik dan Kantor di Kota Medan 
Tabel 3. Skoring Prognostik Sederhana untuk Memprediksi Kejadian Hipertensi Usia Produktif di Kemudian Hari

\begin{tabular}{llcc}
\hline No. & \multicolumn{1}{c}{ Parameter } & Ya & Tidak \\
\hline 1 & Apakah anda gemar mengonsumsi makanan yang asin atau gurih? & 4 & 0 \\
2 & $\begin{array}{l}\text { Apakah anda gemar menyantap makanan cepat saji? } \\
\text { Apakah dalam 1 minggu terakhir ada memiliki lama tidur kurang dari 6 }\end{array}$ & 2 & 0 \\
3 & jam tiap harinya? & 2 & 0 \\
4 & $\begin{array}{l}\text { Apakah ada Gemar mengonsumsi sayur-sayuran? } \\
\text { Apakah anda memiliki penyakit kronis lainnya seperti kolesterol, } \\
\end{array}$ & 0 & 1 \\
& diabetes mellitus, asam urat, dan sebagainya? & 2 & 0 \\
\hline
\end{tabular}

Tabel 3. Besaran Prognostik Menderita Hipertensi di Kemudian Hari

\begin{tabular}{crcr}
\hline Skor & Prognosis & Skor & Prognosis \\
\hline $\mathbf{0}$ & $1,45 \%$ & $\mathbf{6}$ & $58,20 \%$ \\
$\mathbf{1}$ & $3,05 \%$ & $\mathbf{7}$ & $74,82 \%$ \\
$\mathbf{2}$ & $6,29 \%$ & $\mathbf{8}$ & $86,38 \%$ \\
$\mathbf{3}$ & $12,53 \%$ & $\mathbf{9}$ & $93,11 \%$ \\
$\mathbf{4}$ & $23,41 \%$ & $\mathbf{1 0}$ & $96,65 \%$ \\
$\mathbf{5}$ & $39,48 \%$ & & \\
\hline
\end{tabular}

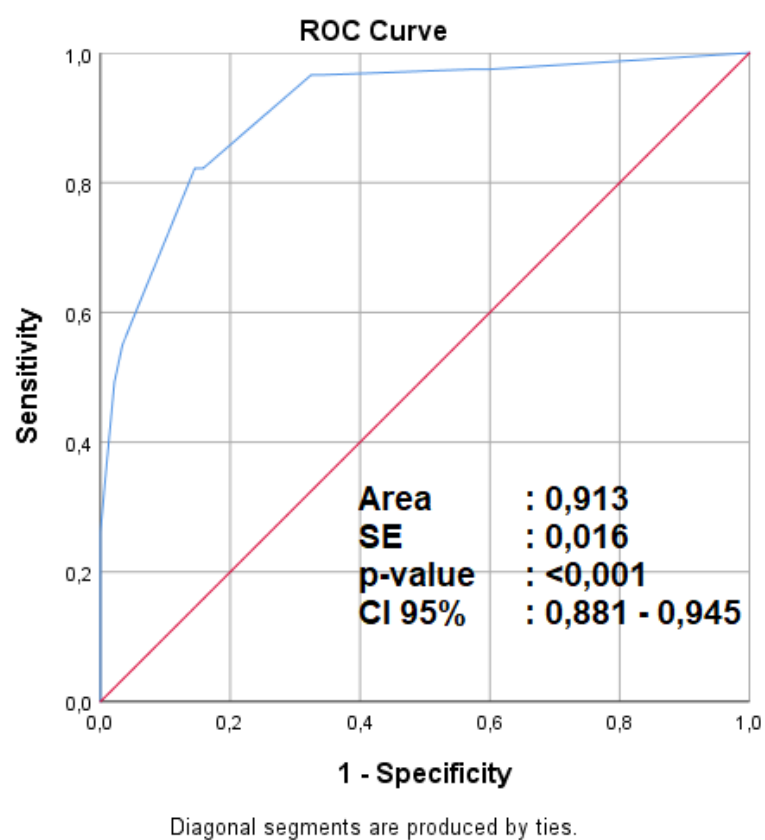

Gambar 2. Kurva ROC Skoring Prognostik Sederhana untuk Memprediksi Kejadian Hipertensi Usia Produktif di Kemudian Hari

Sistem skoring diatas menyatakan bahwa terdapat lima variabel bebas yang berkaitan erat dengan kejadian hipertensi di usia produktif yaitu meliputi konsumsi garam, makanan cepat saji, sayuran, lama tidur kurang dan penyakit kronis. 
Asupan tinggi garam dilaporkan meningkatkan tekanan darah oleh banyak penelitian. Penelitian dari Nihal Ozkayar tahun 2015 dengan judul "The relationship between dietary salt intake and ambulatory blood pressure variability in non-diabetic hypertensive patients" yang melibatkan 136 pasien hipertensi primer (92 pria, 44 wanita) dengan usia rata-rata 50,7 $\pm 11,1$ tahun didapatkan hasil penelitian kadar natrium urin berkorelasi positif dengan rata-rata Average Real Variability (ARV) sistolik 24-jam, dan Average Real Variability (ARV) sistolik malam hari ( $\mathrm{r}=$ $0,371$ dan $\mathrm{p}=0,001, \mathrm{r}=0,329$ dan $\mathrm{p}=0,028)$. Kadar natrium urin berkorelasi positif pula dengan rata-rata Average Real Variability (ARV) diastolik 24 jam dan Average Real Variability (ARV) diastolik malam hari $(\mathrm{r}=0,381$ dan $\mathrm{p}=0,001, \mathrm{r}=0,320$ dan $\mathrm{p}=0,020)$. (Ozkayar et al., 2016)

Penelitian lain dari B.O. Daini, dkk. Yang berjudul "Assessing the association between salt intake, weight status and blood pressure among school children in Ibadan, South-West Nigeria." dengan usia rata-rata responden adalah 13,58 \pm 1,93 tahun, konsumsi rata-rata natrium $2713 \mathrm{mg} /$ hari, serta $67,3 \%$ responden memiliki asupan di atas rekomendasi WHO $\leq 2300 \mathrm{mg} /$ hari dan 16,2\% kelebihan berat badan / obesitas menyatakan prevalensi pre hipertensi dan hipertensi masing-masing pada penelitian ini adalah $28,4 \%$ dan $9,5 \%$. Penelitian ini mengaitkan pola diet natrium dan tekanan darah yang tinggi. Rata-rata tekanan darah sistolik meningkat dengan asupan natrium kuartil dari $104,2 \mathrm{mmHg}$ menjadi $114,7 \mathrm{mmHg}(\mathrm{p}<0,001)$ dan dari $108,1 \mathrm{mmHg}$ menjadi 121,0mmHg pada kelompok dengan kelebihan berat badan / obesitas $(\mathrm{p}=0,003)$. Odds Ratio untuk kejadian prehipertensi dan hipertensi akibat konsumsi natrium berlebih adalah 2,1 (95\% CI: 0,86-5,29) secara keseluruhan dan 2,9 (95\% CI: 1,48-8,03) pada kelompok kelebihan berat badan / obesitas. Asupan natrium dan status berat badan memiliki efek sinergis pada risiko pre hipertensi dan hipertensi (RERI = 0,24). (B.O. Daini, 2018)

Asupan tinggi natrium sebenarnya bukan factor tunggal dari kejadian hipertensi.Penelitian dari Paul N. Jensen, dkk tahun 2018 yang berjudul "The association of estimated salt intake with blood pressure in a Viet Nam national survey" yang mengikutsertakan 2.333 peserta (usia ratarata: 37 tahun, $46 \%$ pria, 33\% hidup di daerah perkotaan). Perkiraan konsumsi garam rata-rata adalah $10 \mathrm{~g} /$ hari. Tidak ada hubungan konsumsi garam dengan tekanan darah atau hipertensi pada jenis kelamin pria atau wanita. Asosiasi tidak berbeda dalam subkelompok yang ditentukan oleh usia, merokok, atau konsumsi alkohol; Namun, asosiasi berbeda antara peserta perkotaan dan pedesaan (nilai $\mathrm{p}$ untuk interaksi status perkotaan / pedesaan dengan konsumsi garam, $\mathrm{p}=$ 0,02), menunjukkan bahwa konsumsi garam yang lebih tinggi dapat dikaitkan dengan tekanan darah sistolik yang lebih tinggi pada penduduk perkotaan tetapi tekanan darah sistolik yang lebih rendah di penduduk pedesaan. (Jensen et al., 2018)

Konsumsi junkfood atau makanan cepat saji dikaitkan memiliki hubungan langsung terhadap kejadian hipertensi. Penelitian dari Bahar Azemati, dkk tahun 2018 yang berjudul "Association between junk food consumption and cardiometabolic risk factors in a national sample of Iranian children and adolescents population: the CASPIAN-V study" dengan rata-rata usia peserta adalah 12,42 $\pm 2,97$ tahun mengungkapkan sindrom metabolik lebih cenderung terjadi pada masyakat yang hidup di daerah perkotaan $(\mathrm{P}=0,004)$ dan memiliki IMT lebih tinggi ( $\mathrm{P}$ $<0,0001)$. Asupan junkfood atau makanan cepat saji tidak terkait dengan kejadian sindrom metabolik; Namun, Asupan junkfood atau makanan cepat saji dikaitkan dengan peningkatan tekanan darah yang tinggi (OR 1,23, 95\% CI 1,09, 1,39), tekanan darah sistolik tinggi (OR 1,38, 95\% CI 1,09, 1,75), dan tekanan darah diastolik tinggi (OR 1,18, 95\% CI 1,04, 1,35), kelebihan 
berat badan (OR 1.22, 95\% CI 1.08, 1.39) dan kelebihan asupan energi (OR 1.14, 95\% CI 1.04, 1.25). (Azemati et al., 2018)

Penelitian lain yang mengungkapkan konsumsi junkfood dengan kejadian hipertensi adalah penelitian dari Sudha Bala, dkk tahun 2017 yang berjudul "Prevalence and determinants of Pre hypertension and Hypertension among urban high school adolescents of Hyderabad" dengan karakteristik berupa total responden 404 siswa, jumlah laki-laki 162 (40,1\%) respoden dan perempuan $242(59,9 \%)$ responden prevalensi Pre Hipertensi sebesar 49 (12\%) dan hipertensi adalah $52(13 \%)$. Usia rata-rata adalah $13,46+1,28$ tahun, rata-rata tekanan darah sistolik adalah $112,99(11,18) \mathrm{mmHg}$ dan rata-rata tekanan darah diastolik adalah 70,84 $(10,74) \mathrm{mm} \mathrm{Hg}$. Kesimpulan penelitian ini adalah gender dan junk food adalah faktor risiko yang berperan pada kejadian pre hipertensi dan hipertensi di kalangan remaja (p-value : 0,028 dan 0,035). (Bala et al., 2017)

Penelitian multifactorial yang membuktikan bahwa konsumsi junkfood merupakan factor dominan terhadap kejadian hipertensi adalah penelitian dari Senthamizh Prasad, dkk tahun 2017, yang berjudul "Elevated Blood Pressure and Its Associated Risk Factors among Adolescents of a North Indian City - A Cross-sectional Study" yang melibatkan 1041 peserta, peningkatan tekanan darah (persentil $\geq 90$ ) lazim pada $24,2 \%$ populasi. Analisa regresi, faktor-faktor seperti obesitas ( $[\mathrm{AOR}]=5,8$, interval kepercayaan 95\% $[\mathrm{CI}]=3,6-9,4)$, diet rendah buah $(\mathrm{AOR}=3,3,95 \% \mathrm{CI}=$ 2,1-5,4), dan konsumsi makanan hunk food ( $\mathrm{aOR}=1,9,95 \% \mathrm{CI}=1,3-2,8)$ meningkatkan kemungkinan kenaikan tekanan darah sementara yang dapat diturunkan dengan olahraga $(\mathrm{aOR}=$ 0,67, 95\% CI = 0,46-0,97). (Prasad et al., 2017)

Konsumsi sayuran dan buah-buahan yang tinggi dikaitkan dengan penurunan tekanan darah secara persisten dikarenakan kandungan kalium yang tinggi pada produk sayur dan buah. Dalam model multivariable yang dilakukan oleh Danika Krupp, dkk dengan judul "Prospective relevance of fruit and vegetable consumption and salt intake during adolescence for blood pressure in young adulthood" disampaikan asupan sayuran dan buah-buahan $100 \mathrm{~g}$ lebih tinggi selama masa remaja secara prospektif berhubungan dengan $0,9 \mathrm{mmHg}$ tekanan darah sistolik yang lebih rendah pada wanita dewasa muda $(\mathrm{P}=0,02)$, tetapi tidak pada kelompok pria $(\mathrm{P}=$ 0,8). (Krupp et al., 2015)

Konsumsi sayur-sayuran dan buah-buahan juga terbukti menurunkan penyakit jantung coroner dari penelitian meta-analisa terdahulu. Penelitian meta-analisa dari Yong Gan, dkk dengan judul "Consumption of fruit and vegetable and risk of coronary heart disease: A meta-analysis of prospective cohort studies" melibatkan dua puluh tiga studi dengan 937.665 peserta dan 18.047 pasien dengan penyakit jantung koroner. Analisis dosis konsumsi sayur dan buah-buah menunjukkan bahwa, RR penyakit jantung koroner adalah 0,88 (95\% CI: 0,85-0,91) pada konsumsi berjumlah $477 \mathrm{~g}$ / hari dari total konsumsi buah dan sayuran, konsumsi 0,84 (95\% CI: 0,75-0,93) per $300 \mathrm{~g} /$ hari asupan buah dan konsumsi 0,82 (95\% CI: 0,73-0,92) per $400 \mathrm{~g} / \mathrm{hari}$ konsumsi sayuran serta adanya hubungan nonlinear risiko PJK dengan konsumsi buah atau sayuran secara terpisah (P untuk nonlinearitas <0,001). (Gan et al., 2015)

Tidur yang baik dan berkualitas sendiri ditentukan oleh 2 hal yaitu dari segi kualitas dan kuantitas. Gangguan tidur yang menyertai akan mengakibatkan peningkatan tekanan darah baik 
secara langsung maupun tidak langsung. Penelitian dari Ru-Qing Liu, dkk tahun 2015 yang berjudul "Poor sleep quality associated with high risk of hypertension and elevated blood pressure in China: results from a large population-based study" mengungkapkan peningkatan risiko atau odds ratio (OR) hipertensi, peningkatan tekanan darah sistolik dan diastolik pada responden dengan gangguan tidur adalah 2,38 (interval kepercayaan 95\% (CI): 2,13-2,65), 2,52 (95\% CI: 2,26-2,80) dan 1,93 (95\% CI : 1.74-2.14) bila disbanding dengan kelompok kontrok. Risiko hipertensi pada orang yang kurang tidur dengan subskala lebih dari 0 pada semua elemen meningkat risiko hipertensi secara signifikan, dengan OR berkisar antara 1,16 (95\% CI: 1,042,30) hingga 3,88 (95\% CI: 1,24-12,16). (Liu et al., 2016)

Penelitian multivariat dari Jang-YoungKim, dkk yang berjudul "A prospective study of total sleep duration and incident metabolic syndrome: the ARIRANG study' yang membandingkan kejadian sindrom metabolik pada kelompok dengan lama tidur 6 hingga 7,9 jam dan kelompok dengan lama tidur kurang dari 6 jam total durasi tidur didapatkan hasil bahwa lama tidur kurang dari 6 jam meningkatkan risiko sebesar 1,41 (1,06-1,88) kali terhadap kejadian sindrom metabolic, 1,30 (0,98-1,69) untuk lingkar pinggang berlebih, $0,75(0,56-0,97)$ untuk kejadian kolesterol, 0,82 (0,60-1,11) untuk kejadian trigliserida tinggi, 1,56 (1,19-2,03) untuk tekanan darah tinggi, dan 1,31 (0,96-1,79) untuk glukosa darah tinggi (Kim et al., 2015)

Penelitian meta-analisa dari OsamuItani, dkk yang berjudul "Short sleep duration and health outcomes: a systematic review, meta-analysis, and meta-regression" dengan total 5.172.710 peserta yang dikumpulkan dari 153 penelitian mengungkap lama tidur yang kurang secara signifikan terkait dengan hasil kematian dini (RR, 1,12; 95\% CI, 1,08-1,16). Hasil signifikan yang serupa diamati pada diabetes mellitus $(1,37,1,22-1,53)$, hipertensi $(1,17,1,09-1,26)$, penyakit kardiovaskular $(1,16,1,10-1,23)$, penyakit jantung koroner $(1,26,1,15-1,38)$, dan obesitas $(1,38,1.25-1.53)$. Analisis met-regresi menemukan hubungan linier antara peningkatan yang signifikan secara statistik dalam mortalitas dan durasi tidur kurang dari enam jam. (Itani et al., 2017)

Penyakit kronis yang akan mempengaruhi kejadian hipertensi sendiri bersifat multifaktorial dan longitudinal. Beberapa contoh penyakit kronis yang akan mencetuskan kejadian hipertensi yaitu

a. Diabetes Mellitus atau Resistensi Insulin

Resistensi insulin berhubungan sangat erat dengan penderita hipertensi, tetapi kurang dengan obesitas. Resistensi insulin dapat secara langsung berperan dalam mempengaruhi dan merangsang pompa kalsium di jaringan yang sensitif terhadap insulin: membuat kalsium keluar dari sel, sehingga terjadi peningkatan jumlah kalsium sistolik di sel adiposa yang dapat menimbulkan resistensi insulin. Kombinasi dari berbagai sistem ini akan menyebabkan vasokonstriksi dan peningkatan tekanan darah. Resistensi insulin terutama terjadi di otot rangka atau hati atau keduanya akan menimbulkan peningkatan sirkulasi insulin dan mengakibatkan resistensi peningkatan sistem saraf adregenik dan peningkatan resistensi di tubulus ginjal. Ini semua juga akan menyebabkan vasokonstriksi pembuluh darah akibat ketidakseimbangan efek langsung vasodilator insulin dan vasokonstriksi yang dicetuskan oleh sistem saraf adregenik (Boudina \& Abel, 2010; Van Buren \& Toto, 2011; Vargatu, 2016)

\section{b. Sindrom Cushing (Hiperkortisolisme)}

Sindroma Cushing (hiperkortisolisme) adalah sebuah peristiwa dimana kelenjar adrenal ginjal terlalu banyak dalam memproduksi kortisol. Hal ini disebabkan oleh karena diabetes meliitus, 
hipertensi, disfungsi gonad, obesitas, atau karena mengkonsumsi obat-obatan tertentu. Kortisol dalam jumlah berlebih akan berdampak pada peningkatan reabsorbsi natrium tubulus ginjal dan meningkatkan ekskresi kalium urin. Reabsorbsi ini akan diikuti oleh retensi air dan garam yang mengakibatkan ekspansi relatif volume plasma, peningkatan curah jantung, dan peningkatan tekanan darah. (Charles et al., 2017; Y. Singh et al., 2011; Vargatu, 2016)

\section{c. Penyakit Ginjal}

Penyakit vaskuler memicu terjadinya kekurangan oksigen atau peristiwa iskemi pada sel dan merangsang sistem renin-angiostensin-aldosteron. Gagal ginjal kronik akan menyebabkan peningkatan sistem renin-angiostensin-aldosteron sebagai akibat dari kerusakan regional yang disebabkan oleh iskemia relatif, aktivitas saraf simpatis yang meningkat akibat kerusakan sebagian besar organ ginjal, hiperparatirod sekunder, dan pemberian obat-obatan eritropoetin (EPO). Selain ketiga penyakit tersebut, stenosis arteri renalis, pielonefritis, glomerulonefritis, tumor-tumor pada ginjal, penyakit turunan seperti penyakit ginjal polikista, trauma atau luka yang mengenai ginjal dan terapi penyinaran yang mengenai ginjal akan berdampak pada peningkatan tekanan darah secara permanen. (M. E. Hall et al., 2014; Van Buren \& Toto, 2011; Webster et al., 2017)

\section{d. Aterosklerosis}

Berdasarkan suatu penelitian aterosklerosis akan memicu pelepasan katelokamin dan bersifat aterogenesis. Mekanisme ini akan mempengaruhi sistem neuroendokrin terhadap dinamika sirkulasi, lemak serum, dan pembekuan darah. Aterosklerosis juga menyebabkan pembuluh darah menjadi tersumbat dan kehilangan kelenturan. Hal ini akan mendorong dan memaksa jantung untuk bekerja lebih kuat dan keras untuk memenuhi tuntutan semua sel yang membutuhkan nutrisi dan suplai oksigen sehingga berdampak pada peningkatan tekanan darah arteri. (J. E. Hall et al., 2012)

e. Terdapat banyak penyakit kronis lainnya yang mencetuskan kejadian hipertensi seperti feokromositoma, aldosteronisme primer, coarctio aorta, hiperaktivitas simpatis, porfiria intermiteen akut, dan lain-lain

\section{KESIMPULAN DAN SARAN}

\section{Kesimpulan}

Lima variabel bebas yaitu konsumsi garam, makanan cepat saji, sayuran, lama tidur kurang dan penyakit kronis berperan secara mandiri terhadap hipertensi (analisis secara "Backward LR", $p$ value < 0.05), yaitu konsumsi garam (p-value <0,001), konsumsi junkfood (p-value 0,001), lama tidur kurang dari 6 jam (p-value 0,008), konsumsi sayur (p-value 0,039), dan penyakit kronis (pvalue 0,006 )

\section{Saran}

Kami merekomendasikan skoring prognostik untuk hipertensi pada usia produktif ini digunakan setelah dilakukan uji lanjutan berupa uji kesahihan dan kehandalan. 


\section{REFERENSI}

Ando, K., \& Fujita, T. (2012). Pathophysiology of salt sensitivity hypertension. In Annals of Medicine. https://doi.org/10.3109/07853890.2012.671538

Azemati, B., Kelishadi, R., Ahadi, Z., Shafiee, G., Taheri, M. Z., Ziaodini, H., Qorbani, M., \& Heshmat, R. (2018). Association between junk food consumption and cardiometabolic risk factors in a national sample of Iranian children and adolescents population: the CASPIANV study. Eating and Weight Disorders. https://doi.org/10.1007/s40519-018-0591-1

B.O. Daini, I. O. A. (2018). Assessing the association between salt intake, weight status and blood pressure among school children in Ibadan, South-West Nigeria. AFRICAN JOURNALS ONLINE (AJOL), 39(1). https://www.ajol.info/index.php/njns/article/view/170744

Badan Penelitian dan Pengembangan Kesehatan. (2013). Riset Kesehatan Dasar 2013. Riset Kesehatan Dasar 2013.

Bala, S., Sandeep, M., Narayana Prasad, G. K., \& Chandrasekhar, A. (2017). Prevalence and Determinants of Pre Hypertension and Hypertension among Urban High School Adolescents of Hyderabad. National Journal of Research in Community Medicine, 6(4), 295. https://doi.org/10.26727/NJRCM.2017.6.4.295-99

Boudina, S., \& Abel, E. D. (2010). Diabetic cardiomyopathy, causes and effects. In Reviews in Endocrine and Metabolic Disorders. https://doi.org/10.1007/s11154-010-9131-7

Charles, L., Triscott, J., \& Dobbs, B. (2017). Secondary Hypertension: Discovering the Underlying Cause. In American family physician.

Chobanian, A. V. (2017). Guidelines for the Management of Hypertension. In Medical Clinics of North America. https://doi.org/10.1016/j.mcna.2016.08.016

Chockalingam, A. (2008). World Hypertension Day and global awareness. Canadian Journal of Cardiology. https://doi.org/10.1016/S0828-282X(08)70617-2

Chockalingam, A., Campbell, N. R., \& Fodor, J. G. (2006). Worldwide epidemic of hypertension. Canadian Journal of Cardiology. https://doi.org/10.1016/S0828282X(06)70275-6

Gan, Y., Tong, X., Li, L., Cao, S., Yin, X., Gao, C., Herath, C., Li, W., Jin, Z., Chen, Y., \& Lu, Z. (2015). Consumption of fruit and vegetable and risk of coronary heart disease: A metaanalysis of prospective cohort studies. International Journal of Cardiology. https://doi.org/10.1016/j.ijcard.2015.01.077

Hall, J. E., Do Carmo, J. M., Da Silva, A. A., Wang, Z., \& Hall, M. E. (2015). Obesity-Induced Hypertension: Interaction of Neurohumoral and Renal Mechanisms. Circulation Research. https://doi.org/10.1161/CIRCRESAHA.116.305697

Hall, J. E., Granger, J. P., do Carmo, J. M., da Silva, A. A., Dubinion, J., George, E., Hamza, S., Speed, J., \& Hall, M. E. (2012). Hypertension: Physiology and pathophysiology. Comprehensive Physiology. https://doi.org/10.1002/cphy.c110058

Hall, M. E., do Carmo, J. M., da Silva, A. A., Juncos, L. A., Wang, Z., \& Hall, J. E. (2014). Obesity, hypertension, and chronic kidney disease. In International Journal of Nephrology and Renovascular Disease. https://doi.org/10.2147/IJNRD.S39739

Houston, M. (2011). The role of magnesium in hypertension and cardiovascular disease. In Journal of Clinical Hypertension. https://doi.org/10.1111/j.1751-7176.2011.00538.x

Itani, O., Jike, M., Watanabe, N., \& Kaneita, Y. (2017). Short sleep duration and health outcomes: a systematic review, meta-analysis, and meta-regression. Sleep Medicine. https://doi.org/10.1016/j.sleep.2016.08.006

Jensen, P. N., Bao, T. Q., Huong, T. T. T., Heckbert, S. R., Fitzpatrick, A. L., LoGerfo, J. P., Van Ngoc, T. Le, \& Mokdad, A. H. (2018). The association of estimated salt intake with blood pressure in a Viet Nam national survey. PLoS ONE. 
https://doi.org/10.1371/journal.pone.0191437

Jike, M., Itani, O., Watanabe, N., Buysse, D. J., \& Kaneita, Y. (2018). Long sleep duration and health outcomes: A systematic review, meta-analysis and meta-regression. In Sleep Medicine Reviews. https://doi.org/10.1016/j.smrv.2017.06.011

Kim, J. Y., Yadav, D., Ahn, S. V., Koh, S. B., Park, J. T., Yoon, J., Yoo, B. S., \& Lee, S. H. (2015). A prospective study of total sleep duration and incident metabolic syndrome: The ARIRANG study. Sleep Medicine. https://doi.org/10.1016/j.sleep.2015.06.024

Knutson, K. L. (2010). Sleep duration and cardiometabolic risk: A review of the epidemiologic evidence. In Best Practice and Research: Clinical Endocrinology and Metabolism. https://doi.org/10.1016/j.beem.2010.07.001

Krupp, D., Shi, L., Egert, S., Wudy, S. A., \& Remer, T. (2015). Prospective relevance of fruit and vegetable consumption and salt intake during adolescence for blood pressure in young adulthood. European Journal of Nutrition. https://doi.org/10.1007/s00394-014-0804-y

Liu, R. Q., Qian, Z., Trevathan, E., Chang, J. J., Zelicoff, A., Hao, Y. T., Lin, S., \& Dong, G. H. (2016). Poor sleep quality associated with high risk of hypertension and elevated blood pressure in China: Results from a large population-based study. Hypertension Research. https://doi.org/10.1038/hr.2015.98

Mahan, L. K., \& Escott-Stump, S. (2008). Krause's Food and Nutrition Therapy. In Krause's Food and Nutrition Therapy.

Ozkayar, N., Dede, F., Ates, I., Akyel, F., Yildirim, T., \& Altun, B. (2016). The relationship between dietary salt intake and ambulatory blood pressure variability in non-diabetic hypertensive patients. Nefrologia. https://doi.org/10.1016/j.nefro.2015.12.004

Pepin, J. L., Borel, A. L., Tamisier, R., Baguet, J. P., Levy, P., \& Dauvilliers, Y. (2014). Hypertension and sleep: Overview of a tight relationship. In Sleep Medicine Reviews. https://doi.org/10.1016/j.smrv.2014.03.003

Perez, V., \& Chang, E. T. (2014). Sodium-to-Potassium Ratio and Blood Pressure, Hypertension, and Related Factors. Advances in Nutrition. https://doi.org/10.3945/an.114.006783

Prasad, S., Masood, J., Srivastava, A. K., \& Mishra, P. (2017). Elevated blood pressure and its associated risk factors among adolescents of a North Indian City-A cross-sectional study. Indian Journal of Community Medicine. https://doi.org/10.4103/ijcm.IJCM_106_16

Singh, R. B., Suh, I. L., Singh, V. P., Chaithiraphan, S., Laothavorn, P., Sy, R. G., Babilonia, N. A., Rahman, A. R. A., Sheikh, S., Tomlinson, B., \& Sarraf-Zadigan, N. (2000). Hypertension and stroke in Asia: Prevalence, control and strategies in developing countries for prevention. In Journal of Human Hypertension. https://doi.org/10.1038/sj.jhh.1001057

Singh, Y., Menon, A., \& Kotwal, N. (2011). Endocrine hypertension - Cushing's syndrome. Indian Journal of Endocrinology and Metabolism. https://doi.org/10.4103/2230-8210.86973

Stolarz-Skrzypek, K., Bednarski, A., Czarnecka, D., Kawecka-Jaszcz, K., \& Staessen, J. A. (2013). Sodium and potassium and the pathogenesis of hypertension. In Current Hypertension Reports. https://doi.org/10.1007/s11906-013-0331-x

Van Buren, P. N., \& Toto, R. (2011). Hypertension in Diabetic Nephropathy: Epidemiology, Mechanisms, and Management. In Advances in Chronic Kidney Disease. https://doi.org/10.1053/j.ackd.2010.10.003

Vargatu, I. (2016). Williams Textbook of Endocrinology. Acta Endocrinologica (Bucharest). https://doi.org/10.4183/aeb.2016.113

Wang, Q., Xi, B., Liu, M., Zhang, Y., \& Fu, M. (2012). Short sleep duration is associated with hypertension risk among adults: A systematic review and meta-analysis. Hypertension Research. https://doi.org/10.1038/hr.2012.91

Webster, A. C., Nagler, E. V., Morton, R. L., \& Masson, P. (2017). Chronic Kidney Disease. In 
The Lancet. https://doi.org/10.1016/S0140-6736(16)32064-5

Zhao, D., Qi, Y., Zheng, Z., Wang, Y., Zhang, X. Y., Li, H. J., Liu, H. H., Zhang, X. T., Du, J., \& Liu, J. (2011). Dietary factors associated with hypertension. In Nature Reviews Cardiology. https://doi.org/10.1038/nrcardio.2011.75 